\title{
Migratory Patterns, Structure, Abundance, and Status of Bull Trout Populations from Subbasins in the Columbia Plateau
}

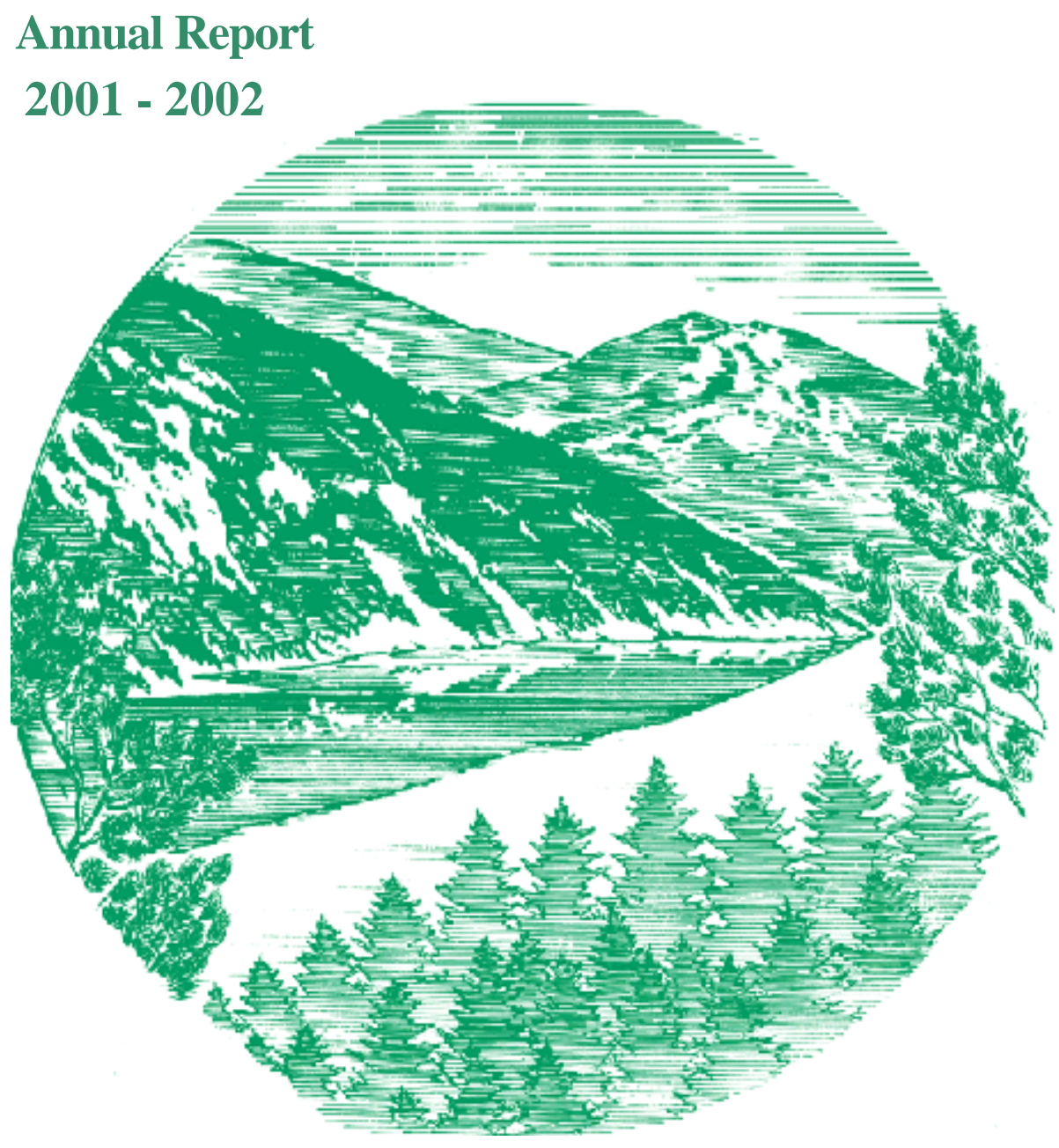

DOE/BP-00004101-2

May 2003 
This Document should be cited as follows:

Sankovich, Paul, Stephanie Gunckel, Alan Hemmingsen, Ian Tattam, Philip Howell, "Migratory Patterns, Structure, Abundance, and Status of Bull Trout Populations from Subbasins in the Columbia Plateau", Project No. 1994-05400, 37 electronic pages, (BPA Report DOE/BP-00004101-2)

Bonneville Power Administration

P.O. Box 3621

Portland, Oregon 97208

This report was funded by the Bonneville Power Administration (BPA), U.S. Department of Energy, as part of BPA's program to protect, mitigate, and enhance fish and wildlife affected by the development and operation of hydroelectric facilities on the Columbia River and its tributaries. The views in this report are the author's and do not necessarily represent the views of BPA. 
Migratory Patterns, Structure, Abundance, and Status of Bull Trout Populations from Subbasins in the Columbia Plateau

2002 Annual Report

\author{
Prepared by: \\ Paul M. Sankovich \\ Stephanie L. Gunckel \\ Alan R. Hemmingsen \\ Ian A. Tattam \\ Oregon Department of Fish and Wildlife \\ Portland, Oregon \\ and \\ Philip J. Howell \\ USDA Forest Service \\ Pacific Northwest Research Station \\ La Grande, OR \\ Prepared for: \\ U.S. Department of Energy \\ Bonneville Power Administration \\ Environment, Fish and Wildlife \\ P.O. Box 3621 \\ Portland, OR 97208-3621 \\ Project Number 199405400 \\ Contract Number 4101
}

May 2003 


\section{Contents}

$\underline{\text { Page }}$

I. Fine-scale population structure of bull trout in the John Day River subbasin..... 1

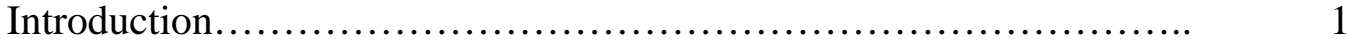

Methods.......................................................... 2

Results and Discussion........................................... 2

II. Migratory patterns of bull trout in the Umatilla and John Day River subbasins.... 4

Introduction..................................................... 4

Methods........................................................ 5

Results and Discussion......................................... 7

III. Comparing methods of estimating the abundance of adult bull trout............. 9

Introduction................................................. 9

Methods........................................................ 9

Results and Discussion.......................................... 12

IV. Monitoring the abundance of adult bull trout in the Walla Walla, Umatilla, John Day, and Deschutes River subbasins using the Environmental Monitoring and Assessment Program (EMAP) protocol................................... 16

Introduction................................................. 16

Methods......................................................... 16

Results and Discussion.......................................... 18

Acknowledgements................................................... 23

References............................................................ 24

Appendix A. Movements of radio-tagged bull trout in the Umatilla River subbasin...... 27 


\section{Tables}

Number

$\underline{\text { Page }}$

1. Location, number, and fork length statistics of bull trout sampled in the John Day River drainage in 1995 and 2002 for genetic analyses.

2. Date of tagging, radio tag frequency, fork length, weight, and capture and release location of fifteen bull trout from the Umatilla River drainage, 2002.......

3. Number, sex, and maturity status of bull trout captured in an upstream migrant trap in Mill Creek in 2002

4. Number of pools in the mainstem of Mill Creek, number of pools sampled, and mean density (number per pool) and estimated abundance of unmarked bull trout $\geq 300 \mathrm{~mm}$ FL in 2002

5. Location, number, sex, and maturity status of bull trout $<300 \mathrm{~mm}$ FL sampled in Mill Creek and its tributaries in 2002 .

6. Length and maturity status of bull trout $<300 \mathrm{~mm}$ fork length sampled in Mill

7. Redd counts in the Mill Creek drainage in 2002.

8. Bull trout redds counted in survey sections (n) and estimated to be within three

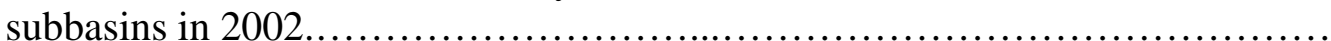

9. Comparison of two strategies used to count bull trout redds in the Walla WallaUmatilla subbasin in 2002 


\section{Figures}

Number $\quad \underline{\text { Page }}$

1. Map of the John Day River subbasin showing the location of streams where bull trout were sampled in 1995 and 2002 for genetic analyses.................

2. Map of the Umatilla River drainage showing landmarks and river kilometers

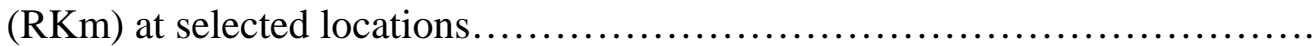

3. Map of Mill Creek study are showing landmarks and units in which redds

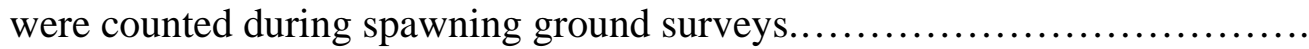

4. Location, status, and number of bull trout redds $/ \mathrm{km}$ for sampling sites in the Walla Walla River and Umatilla River subbasins, OR........................

5. Location, status, and number of bull trout redds $/ \mathrm{km}$ for sampling sites in the North Fork, Middle Fork, and mainstem John Day rivers, OR

6. Location, status, and number of bull trout redds/km for sampling sites in the Warms Springs and Metolius River drainages, OR............................ 


\section{Appendix Tables}

Number

$\underline{\text { Page }}$

A-1. Locations of radio-tagged bull trout in the Umatilla and North Fork Umatilla rivers during tracking events from June to February 2003 ....................... 


\section{Appendix Figures}

Number $\quad \underline{\text { Page }}$

A-1. Locations of bull trout with radio tag freqencies 150.162, 150.172, 150.182, 150.191, and 150.212 during tracking events from June 2002 to February 2003.

A-2. Locations of bull trout with radio tag freqencies 150.223, 150.232, 150.243, 150.252, and 150.752 during tracking events from June 2002 to February 2003

A-3. Locations of bull trout with radio tag freqencies 150.772, 150.792, 151.071, 151.291, and 151.753 during tracking events from June 2002 to February 2003 


\section{Fine-scale population structure of bull trout in the John Day River subbasin}

\section{Introduction}

Metapopulation theory has been increasingly applied to salmonid management and research in general (Rieman and Dunham 2000) and specifically to bull trout Salvelinus confluentus (e.g., Rieman and McIntyre 1993). There is little empirical evidence to guide that application, however (Rieman and Dunham 2000). If or how bull trout populations are actually organized and function as metapopulations remain largely untested hypotheses. Empirical estimates of dispersal that may link local populations to a larger population are one of the fundamental needs for increasing our understanding of metapopulation dynamics in bull trout (Rieman and Dunham 2000). Currently, DNA microsatellite analysis is the best tool available to obtain such estimates.

We previously used DNA microsatellite analysis to describe the broad-scale structure of 65 bull trout populations in the Northwest (Bellerud et al. 1997; Spruell and Allendorf 1997; Spruell et al. 2003). That analysis included populations from the Deschutes, John Day, Umatilla, and Walla Walla river subbasins, as well as other populations from the Columbia and Klamath basins and coastal Washington. There was substantial genetic differentiation among populations but little within them. Three major regional groups of bull trout were identified: Coastal, Snake River, and Clark Fork River.

It is still not known how bull trout populations are structured within these regional groups. Given the results from our analysis, and telemetry data describing the extent of bull trout migrations, it is reasonable to suspect that metapopulation structure, if it exists, occurs at a smaller scale (i.e., within tributary basins). Our previous analysis was limited to the use of four DNA microsatellite loci that offered limited power to discriminate fine-scale population structuring within metapopulations. Recently, however, researchers have started to use new loci in their microsatellite analyses (Spruell et al. 1999). These loci have increased the levels of variation observed in the analysis and may be useful in providing increased resolution among bull trout populations (Spruell et al. 1999). Some preliminary, exploratory analysis of samples from the John Day and Grande Ronde river subbasins using additional loci developed since our earlier work suggests possible structuring of bull trout populations within those basins. Such structuring would have significant implications for management activities and recovery efforts.

The objective of this study is to evaluate the fine-scale population structure of bull trout in the John Day River subbasin. We collected genetic samples from bull trout in ten streams in this subbasin in 1995 as part of the previous analysis (Spruell et al. 2003). In 2002, we attempted to collect additional samples from two streams with previous sample sizes of less than 25 , and sampled in four streams where bull trout had not previously been collected, in order to increase the power of the analysis. We also sampled additional bull trout in five of the original streams to test for temporal variation in allele frequencies. Archived samples from 1995 will be re-analyzed using six new loci, and samples collected in 2002 will be analyzed using all ten loci

presently available. The genetic analyses will be completed subsequent to the publication of this report. Consequently, we report here only on the collection of genetic samples in 2002. 


\section{Methods}

We sampled bull trout in tributaries to the upper John Day River and to the North Fork and Middle Fork John Day rivers in June and July 2002 (Table 1 and Figure 1). Our objective was to sample 30 fish in each stream, except Indian, Clear (Middle Fork John Day), South Fork Desolation, and Clear (North Fork John Day) creeks. In Indian and South Fork Desolation creeks, we intended to capture sufficient numbers of bull trout to bring the total sample size (1995 and 2002 combined) for each stream up to 25-30 individuals. Additional samples were not needed from either of the two Clear creeks.

We collected bull trout by electrofishing or angling. To reduce the likelihood of sampling related individuals, we sampled in haphazardly selected reaches throughout the distribution of bull trout and collected fish of different sizes (i.e., ages) in each steam. We anesthetized captured bull trout in tricaine methane sulfonate (MS-222), measured their fork length, and removed a portion of their caudal fin. Each caudal fin sample was divided between two uniquely numbered vials containing $95 \%$ ethanol and stored for subsequent analysis at the University of Montana's Wild Trout and Salmon Genetics Laboratory.

Table 1. Location, number, and fork length statistics of bull trout sampled in the John Day River drainage in 1995 and 2002 for genetic analysis.

\begin{tabular}{llccccc}
\hline & & 1995 & 2002 & & \multicolumn{2}{c}{ Fork Length (mm) } \\
\cline { 6 - 7 } \multicolumn{1}{c}{ Subbasin } & \multicolumn{1}{c}{ Stream } & sample & sample & Total & Mean & SD \\
\hline Upper John Day & Indian Cr. & 16 & 0 & 16 & 161 & 48 \\
Upper John Day & Call Cr. & 32 & 30 & 62 & 147 & 44 \\
Upper John Day & Deardorff Cr. & & 30 & 30 & 131 & 75 \\
Upper John Day & Rail Cr. & & 30 & 30 & 134 & 71 \\
Upper John Day & Roberts Cr. & & 30 & 30 & 94 & 29 \\
Upper John Day & Reynolds Cr. & & 0 & 0 & - & - \\
M. F. John Day & Granite Boulder Cr. & 25 & 30 & 55 & 114 & 40 \\
M. F. John Day & Big Cr. & 30 & 30 & 60 & 136 & 33 \\
M. F. John Day & Clear Cr. & 25 & & 25 & 123 & 36 \\
N. F. John Day & S. F. Desolation Cr. & 17 & 5 & 22 & 158 & 30 \\
N. F. John Day & Clear Cr. & 30 & & 30 & 126 & 22 \\
N. F. John Day & Baldy Cr. & 30 & 30 & 60 & 147 & 52 \\
N. F. John Day & S. F. Trail Cr. & 26 & 30 & 56 & 157 & 89 \\
\hline
\end{tabular}

\section{Results and Discussion}

We met our objectives in all but three streams in 2002. We found no bull trout in Indian and Reynolds creeks and only five in South Fork Desolation Creek (Table 1). Indian and South Fork Desolation creeks will be sampled again in 2003 in an attempt to increase sample sizes to 25-30 individuals. Reynolds Creek will not be re-sampled. We substituted Roberts Creek for Reynolds Creek after finding no fish in the latter stream in 2002. 
Figure 1. Map of the John Day River subbasin showing the location of streams where bull trout were sampled in 1995 and 2002 for genetic analyses. 


\section{Migratory patterns of bull trout in the Umatilla and John Day River subbasins}

\section{Introduction}

Bull trout populations are composed of resident or migratory individuals, and perhaps of both. Whether the two life history forms make up a single population or separate populations in systems where they occur together is not known (Rieman and McIntyre 1993). Resident bull trout remain in their natal tributary throughout life. Migratory bull trout rear in their natal tributary as juveniles, migrate to and rear in a larger river or lake as subadults, and return to their natal tributary as adults to spawn. Bull trout are capable of repeat spawning and may spawn every year or in alternate years (Fraley and Shepard 1989; Pratt 1992). Migratory fish that survive spawning subsequently return to a larger river or lake to feed and grow.

Timing of migration to and from the natal tributary and timing of spawning vary among migratory adults. Migratory adults generally ascend their natal tributary in spring or summer and spawn in late summer or early fall (as do resident adults). They leave their natal tributary shortly after spawning and spend winter in a larger water body. Bull trout that migrate within a stream system versus between a lake and stream system are termed fluvial and adfluvial, respectively. Fluvial adults that have spawned previously but are not reproductively mature in a given year may nevertheless migrate into headwater reaches along with mature adults in spring or summer to avoid increasing water temperatures in areas downstream.

Determining the timing of seasonal movements of migratory bull trout, and the geographic extent of these movements, is critical to bull trout protection and recovery efforts. Migratory individuals are important to the persistence of local populations (Rieman and McIntyre 1993). Identifying migratory corridors and spawning and overwintering areas that migratory bull trout rely upon can help focus habitat protection and resoration efforts.

From 1998-2000 the Oregon Department of Fish and Wildlife (ODFW) studied the migratory behavior of fluvial adult-sized bull trout captured and radio-tagged in the upper Umatilla and North Fork Umatilla rivers (J. Germond, ODFW, personal communication), where most, if not all, of the fluvial fish in the subbasin originate. The study shed light on summer and fall movements of fluvial adults; however, most of the radio-tagged fish that had been observed migrating relatively far downstream after the fall spawning period were subsequently lost and never relocated. As a result, the migratory corridor and overwintering areas used by fluvial adults were not fully defined. One objective of this study, therefore, is to describe the seasonal distribution and movement of fluvial adult bull trout in the Umatilla River subbasin, with particular emphasis on identifying overwintering areas and the extent of the migratory corridor.

Resident bull trout inhabit many of the streams in the North Fork and Middle Fork John Day River drainages. Fluvial bull trout have rarely been observed in these drainages and information on their migratory patterns is limited to observations on two fish we radio-tagged in spring 1999 in the mainstem John Day River, approximately $24 \mathrm{~km}$ downstream from its confluence with the North Fork. These fish migrated upstream into the North Fork John Day River and eventually into its upper reaches before being lost in summer 1999 (Hemmingsen et al. 
2001a). The second objective of this study is to begin to identify streams in the North Fork and Middle Fork John Day River drainages that support fluvial bull trout and to describe the seasonal distribution and movement of fluvial adults from those systems.

\section{Methods}

To monitor the movement of bull trout in the Umatilla River drainage, we surgically implanted radio transmitters in 15 fluvial adult-sized $(\geq 300 \mathrm{~mm}$ fork length (FL)) bull trout (Table 2). These fish were captured by angling in the upper Umatilla and lower North Fork Umatilla rivers (Figure 2) from 3 June to 2 July 2002 (Table 2). We carried our tagging equipment in a backpack as we fished and performed surgery on bull trout as they were captured. We held captured fish in a live net in a shaded area of the stream while setting up our tagging equipment on the stream bank. We soaked all surgical instruments and tags in $100 \mathrm{ppm}$ Argentyne for at least 10 minutes prior to each surgery, then rinsed these items in distilled water. Fish were anesthetized prior to surgery by placing them in an aerated bath containing 50-70 $\mathrm{mg} / \mathrm{L}$ MS-222 buffered with $120 \mathrm{mg} / \mathrm{L}$ sodium bicarbonate. While waiting for the fish to fall deeply enough under anesthesia to undergo surgery, we weighed and measured them and injected a $134 \mathrm{kHz}$ passive integrated transponder (PIT) tag into their cheek.

We performed surgery with the fish placed ventral side up in a v-shaped tagging cradle. We used a baster to irrigate the gills with anesthetic solution and periodically moisten the body.

Table 2. Date of tagging, radio tag frequency, fork length, weight, and capture and release location of fifteen bull trout from the Umatilla River drainage, 2002.

\begin{tabular}{rccccr}
\hline $\begin{array}{c}\text { Date of } \\
\text { Tagging }\end{array}$ & Tag Frequency & $\begin{array}{c}\text { Fork Length } \\
(\mathrm{mm})\end{array}$ & Weight $(\mathrm{g})$ & Stream & Rkm \\
\hline $06 / 03 / 02$ & 150.243 & 513 & na & N. F. Umatilla R. & 0.3 \\
$06 / 12 / 02$ & 150.182 & 376 & 680 & Umatilla R. & 137.6 \\
$06 / 12 / 02$ & 150.232 & 351 & 524 & Umatilla R. & 137.6 \\
$06 / 12 / 02$ & 151.291 & 490 & 1248 & Umatilla R. & 138.2 \\
$06 / 17 / 02$ & 150.792 & 384 & 732 & Umatilla R. & 142.3 \\
$06 / 17 / 02$ & 150.752 & 377 & 708 & Umatilla R. & 143.6 \\
$06 / 19 / 02$ & 150.772 & 365 & 656 & Umatilla R. & 143.6 \\
$06 / 21 / 02$ & 150.252 & 383 & 742 & Umatilla R. & 137.6 \\
$06 / 24 / 02$ & 151.071 & 482 & 1260 & Umatilla R. & 142.3 \\
$06 / 26 / 02$ & 150.162 & 375 & 628 & Umatilla R. & 139.9 \\
$06 / 26 / 02$ & 150.191 & 405 & 840 & Umatilla R. & 138.3 \\
$06 / 27 / 02$ & 150.223 & 385 & 666 & Umatilla R. & 143.2 \\
$06 / 27 / 02$ & 151.753 & 385 & 690 & N. F. Umatilla R. & 1.4 \\
$07 / 02 / 02$ & 150.172 & 390 & 780 & N. F. Umatilla R. & 1.4 \\
$07 / 02 / 02$ & 150.212 & 486 & 1,362 & N. F. Umatilla R. & 2.9 \\
\hline
\end{tabular}




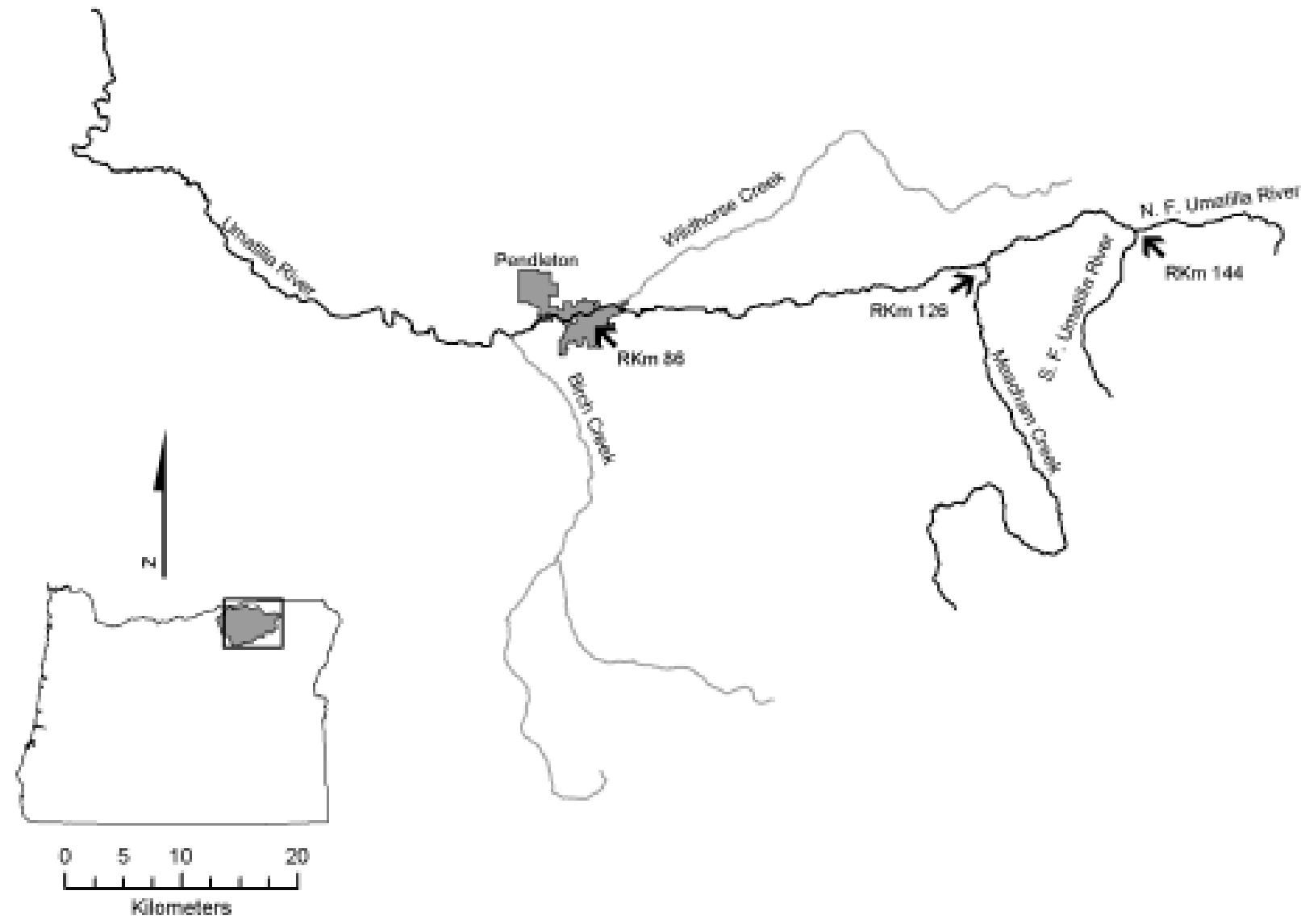

Figure 2. Map of the Umatilla River drainage showing landmarks and river kilometers (RKm) at selected locations.

We began the surgery by making an incision about equal in length to the diameter of the radio tag and slightly anterior and dorsal to the pelvic girdle. We inserted a $152 \mathrm{~mm}$, 16-gauge hypodermic needle into the incision, guided the needle along the body wall, and pushed about 25 $\mathrm{mm}$ of its end out the body wall at a point $10-20 \mathrm{~mm}$ posterior and dorsal to the base of the pelvic fin. We then inserted the full length of the radio tag's antenna into the dull end of the needle, which was protruding from the incision, and pulled on the needle's sharpened end to remove the needle entirely from the fish and leave the antenna trailing from the body. The radio tag was inserted in the abdominal cavity by pulling gently on the antenna while pushing the tag into the incision. We closed the incision with non-absorbable, 3/0, polyamide suture and surgical adhesive. We used sterile gauze to blot dry the incision and sutures before applying surgical adhesive to them. Each bull trout was allowed to recover from anesthesia in an aerated container of water before being released in a slow-flowing section of stream near its capture site. All surgeries were performed at stream temperatures less than $15^{\circ} \mathrm{C}$.

The radio tags we used (model 2-357, Advanced Telemetry Systems) emit a pulsed signal in the $150-151 \mathrm{MHz}$ range. Their warranty life is 280 days, but we expect them to function for 
about 18 months based on past experience. The tags weigh $7.3 \mathrm{~g}$ in air and were $1.4 \%$ or less of the weight of the bull trout we tagged.

We tracked radio-tagged bull trout in the Umatilla River system by vehicle and on foot (in the North Fork Umatilla Wilderness) from June through September 2002. We began tracking by airplane in October, when we expected the fish to begin migrating downstream to overwintering areas, some of which were not accessible by road. We continued ground tracking in October and November in an attempt to locate radio tags of fish we suspected might be dead, based on their lack of downstream movement. We tracked twice in June, once each in July and August, bi-monthly from September through November, and monthly from December to the present (March 2003).

When tracking by vehicle or foot, we used triangulation and manipulated the receiver's gain setting to pinpoint the location of each radio-tagged fish. When tracking by air, we recorded the location where the strongest signal was received from a fish's radio tag. The airplane had an $\mathrm{H}$-antenna attached to each strut, and both antennas operated simultaneously as we flew up or down the stream. In all types of tracking, a global positioning unit was used to obtain coordinates for the observer's position upon locating a fish. The coordinates were later entered into a computer program (MAPTECH's Terrain Navigator) to determine fish locations. In cases where the plotted coordinates were not in, or immediately adjacent to, the stream channel (because the road or trail was away from the stream, or the airplane was not directly over it), the fish's location was determined to be at a point in the stream that was the shortest distance away from the observer's plotted location.

We radio-tagged no bull trout in the John Day River system in 2002. We had planned to tag bull trout captured incidentally in the lower John Day River from February to May by personnel from ODFW's John Day Basin Chinook Salmon Escapement and Productivity Monitoring project. However, we did not receive our radio tags from the manufacturer until mid-May due to the timing with which our funding was provided, and no bull trout were captured incidentally thereafter.

\section{Results and Discussion}

All of the bull trout we radio-tagged in the Umatilla River drainage survived surgery and retained their transmitters for at least two months after tagging, as evidenced by their patterns of movement upstream (Appendix Figures A-1 to A-3 and Appendix Table A-1). In general, the bull trout moved from the Umatilla River into the North Fork Umatilla River in July, reached their upper limit of movement in the North Fork between mid-September and early October, and began to migrate downstream between late September and mid-October (Appendix Figures A-1 to A-3 and Appendix Table A-1). The bull trout were distributed up to river kilometer (RKm) 9 in the North Fork during the September-October spawning period. In November, we recovered the transmitters of six bull trout and could not find two transmitters that, based on their location, were either in dead fish or had been rejected. These eight transmitters were all located in or adjacent to the North Fork Umatilla River. The remaining seven transmitters appeared to be in live bull trout that emigrated from the North Fork after the spawning period and are currently 
(March 2003) overwintering in the Umatilla River between RKm 118 and 143, well upstream from the town of Pendleton, Oregon (Figure 2).

Our findings regarding the seasonal distribution and movement of bull trout are generally consistent with those from a previous study in the Umatilla River drainage (J. Germond, ODFW, personal communication). However, whereas all of the bull trout we radio tagged entered the North Fork Umatilla during the spawning period, one radio-tagged bull trout each in $1998(\mathrm{n}=6)$ and $1999(n=13)$ spent the spawning period in the upper Umatilla River. These fish were 280 $\mathrm{mm}$ and $496 \mathrm{~mm}$ FL when tagged in June 1998 and July 1999, respectively. Whether they were mature is not known. Upstream movement by the smaller fish in spring 1999 indicated it was alive and had retained its transmitter through the spawning period in 1998. The larger fish moved little after being tagged and was never visually observed to determine whether it had died or lost its transmitter.

The previous study also documented more extensive downstream movement after the spawning period than we have observed thus far. One individual in the prior study was located at RKm 63 (approximately 22 RKm downstream from Pendleton, OR) on 17 May 2000, after having been last observed at RKm 110 on 17 November 1999. This fish remained at its May location through July, when it was located last. It presumably was dead in July (and perhaps earlier), given water temperatures in the Umatilla River at that time of year. Whether the movements of this fish represented those of a healthy fish or one moving downstream while dying is not clear. Nevertheless, based on captures of bull trout at collection facilities and in fisheries between RKm 5 and RKm 98 (U.S. Fish and Wildlife Service 2002), it is evident that fluvial bull trout do migrate to and utilize the lower Umatilla River, and perhaps even the Columbia River. This type of behavior appears to be expressed infrequently and, therefore, might not always be observed in a telemetry study like ours where a small portion of the population was radio-tagged and observed over a relatively short timeframe. 


\section{Comparing methods of estimating the abundance of adult bull trout}

\section{Introduction}

Quantitative estimates of bull trout abundance are required to determine the status of populations, monitor changes in population size, and evaluate the effectiveness of conservation strategies. Little data are available on bull trout abundance and population trends (Rieman and McIntyre 1993). Obtaining such information has been identified as a critical research need (Rieman and McIntyre 1993; Buchanan et al. 1997). Redd counts typically have been used to monitor bull trout abundance and evaluate population trends (Rieman and Myers 1997). Counting redds is an attractive technique because it is relatively easy, inexpensive, and unintrusive compared to other methods of monitoring, and is thought to provide an indirect measure of adult abundance (i.e., of breeding population size).

Despite their frequent use, redd counts may not be sufficient or appropriate to quantify bull trout abundance. Detecting changes in population size may not be possible using the most extensive sets of redd count data available (7-17 years) (Maxell 1999) and is unlikely for populations for which more limited data sets exist (Rieman and Myers 1997). Errors in redd identification not considered in these earlier analyses may further limit the utility of redd counts. Recent studies have shown substantial sampling error associated with counts of bull trout redds (Bonneau and LaBar 1997; Dunham et al. 2001; Hemmingsen et al. 2001b). In addition, we have found that redd counts may not relate well to the abundance of resident adult bull trout (Hemmingsen et al. 2001c), which build relatively small and inconspicuous redds compared to those of fluvial and adfluvial adults.

Standard, appropriate, and powerful methods to assess bull trout abundance across all ranges of habitats have not been established (see Bonar et al. 1997). Although data are beginning to accumulate on the validity of bull trout redd counts (Bonneau and LaBar 1997; Dunham et al. 2001; Hemmingsen et al. 2001b,c), more information is needed to fully evaluate this monitoring technique. The objective of this study is to compare redd counts to other measures of adult bull trout abundance in the Mill Creek drainage (Walla Walla River subbasin), which supports fluvial and resident fish. In 2002, our specific approach was to estimate the abundance of mature fluvial and resident females and subsequently count redds in the drainage in order to assess the relationship between the redd count and the number of mature females.

\section{Methods}

This study was conducted at and upstream from a dam and intake structure in Mill Creek that supplies water to the city of Walla Walla (Figure 3). A ladder on the dam provides passage for upstream migrants. Most fluvial adult bull trout in the Mill Creek drainage appear to overwinter downstream from the dam (Hemmingsen et al. 2001a,b,c,d; 2002) and utilize the ladder when returning to spawning areas in spring and summer (P.M. Sankovich, unpublished data). Some fish, however, may jump the dam or overwinter upstream from it. Therefore, we took a two-pronged approach to estimating the abundance of mature fluvial females. In addition to identifying, counting, and marking fluvial females trapped at the ladder, we estimated the 


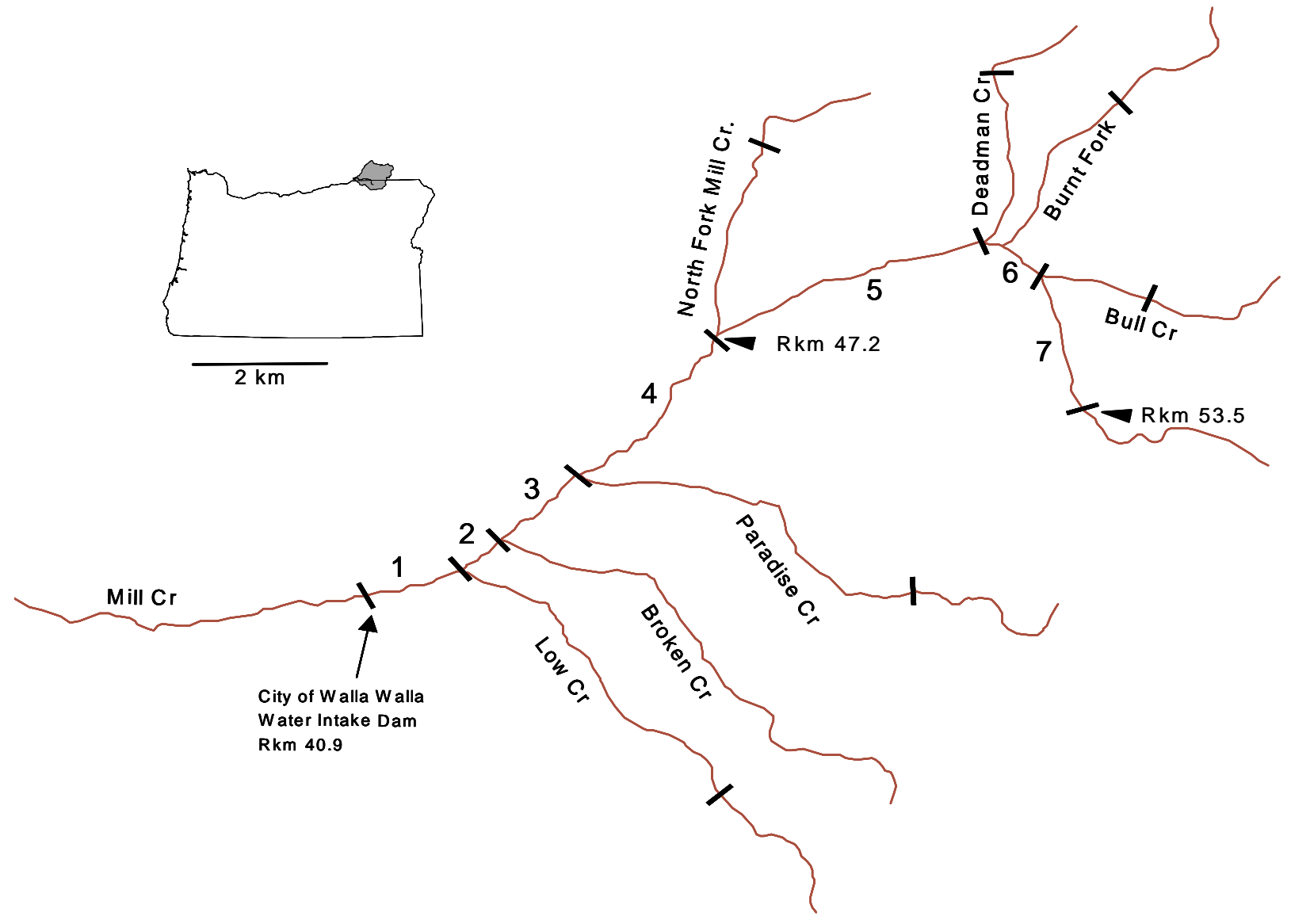

Figure 3. Map of the Mill Creek study area showing landmarks and units in which redds were counted during spawning ground surveys.

abundance of unmarked fluvial females in the drainage upstream from the dam.

We operated a trap, designed as described in Hemmingsen et al. (2001b), at the head of the dam's ladder from 4 June to 8 October 2002. We waited until June to install the trap because only three bull trout were captured prior that month in 1998-2001 (Hemmingsen et al. 2001a,b,c; 2002). The trap was usually checked daily but sometimes as infrequently as every third day during periods when few fish had been trapped historically. As in previous years, bull trout trapped at the ladder were anesthetized, measured, weighed, interrogated for a PIT tag, and, if no PIT tag was present, injected with one (Hemmingsen et al. 2001a,b,c; 2002). In 2002, each fish was also inspected for maturity using ultrasound and marked by removing its adipose fin. Only mature (or maturing) female bull trout could be identified using ultrasound. Mature males could not be identified or distinguished from any immature males or females that might have been captured.

To estimate the abundance of unmarked, mature fluvial females upstream from the dam, we first estimated the abundance of unmarked fish $\geq 300 \mathrm{~mm}$ FL using modified Hankin and Reeves-type methods (Hankin and Reeves 1988). We considered fish $\geq 300 \mathrm{~mm}$ FL to be fluvial adults for two reasons. First, few fluvial fish < than $300 \mathrm{~mm}$ FL were trapped at the ladder each 
year prior to 2002 (Hemmingsen et al. 2001a,b,c; 2002). Second, in other streams in northeast Oregon where only resident bull trout are present, we have not observed bull trout $\geq 300 \mathrm{~mm}$ FL.

Habitat surveys were conducted in mid-July. We classified habitat into three categories - pools, riffles, and glides — to simplify the classification of habitat units. From late July to mid-Augst, we snorkeled a systematic sample of pools and block-netted and electrofished a systematic sample of riffles and glides in the mainstem of Mill Creek. In the tributaries, where most of the pools were too small and shallow to snorkel efficiently, we simply block-netted and electrofished a systematic sample of riffle/pool units. The abundance of unmarked fish $\geq 300$ mm FL was subsequently estimated by expanding 1) average density in sampled pools across the total number of pools in the mainstem, 2) average densities in sampled riffles and glides across the estimated area of those habitat types in the mainstem, and 3) average density in riffle/pool units across the area of riffle/pool units in the tributaries. These expanded numbers were then summed. Because we wanted to minimize electroshocking of fluvial adult bull trout, we did not calibrate our snorkel counts of unmarked fish $\geq 300 \mathrm{~mm}$ FL according to our snorkeling efficiency (i.e., we did not attempt to obtain removal estimates for these fish in a sample of block-netted pools). In addition, we did not attempt to obtain removal estimates for unmarked fish $\geq 300 \mathrm{~mm}$ when electrofishing riffles, glides, and riffle/pools units. The density estimates in these habitat types were based simply on the count of unmarked fish $\geq 300 \mathrm{~mm}$ FL captured while we were obtaining multiple pass removal estimates ( $75 \%$ reduction) for fish $<300 \mathrm{~mm} \mathrm{FL}$ (see below).

To calculate the estimated abundance of mature fluvial females, we assumed they were as prevalent among the unmarked fish $\geq 300 \mathrm{~mm}$ FL, and among a small number of fish captured in the trap before we received our ultrasound equipment, as they were among fish inspected for maturity at the trap. The abundance of mature fluvial females, then, was calculated as

$$
M=T+U(T / I)+N(T / I)
$$

where $\mathrm{M}=$ the total abundance of mature fluvial females, $\mathrm{T}=$ the trap count of mature fluvial females, $\mathrm{U}=$ the estimated abundance of unmarked fish $\geq 300 \mathrm{~mm} \mathrm{FL}, \mathrm{I}=$ the number of fish trapped and inspected using ultrasound, and $\mathrm{N}=$ the number of fish trapped but not inspected using ultrasound.

To estimate the abundance of mature resident females, we first estimated the abundance of bull trout $125-299 \mathrm{~mm}$ FL upstream from the dam. Work we have done elsewhere has indicated that resident fish do not mature until they are $125 \mathrm{~mm}$ FL or larger. Fish $\geq 300 \mathrm{~mm}$ FL were likely to be fluvial adults for reasons noted above. The abundance estimate for fish $125-$ $299 \mathrm{~mm}$ FL was obtained simultaneously with the abundance estimate for unmarked fish $\geq 300$ mm FL, using similar methods. For the smaller size class of fish, however, we obtained removal estimates when electrofishing and calibrated our snorkel counts.

We next estimated the percentage of mature resident females among the fish in the 125$299 \mathrm{~mm}$ FL size-class. We did this by using an endoscope to examine the reproductive organs of a sample of the fish captured during the removal estimates. A small incision was made near the pelvic fin to insert the endoscope into the abdominal cavity. The incision was closed with one or 
two sutures after the examination. The abundance estimate for mature resident females was obtained by multiplying the abundance estimate for fish $125-300 \mathrm{~mm}$ FL by the percentage of mature females among the fish examined via endoscopy.

Redd counts in the study area were conducted three times between mid-September and late October, throughout all spawning areas. During each survey, we flagged newly observed redds, identified them with a unique number, and noted all fish observed on or off redds.

\section{Results and Discussion}

Bull trout were captured in the trap during the first day of operation, indicating that some may have passed the ladder before the trap was installed. In all, 181 bull trout were captured (Table 3). Three arrived before we received our ultrasound equipment and were not inspected for maturity. Eighty-eight were identified as mature females, and 89 were identified as either mature males or immature fish. One of the fish captured was not marked or inspected because it escaped while the trap was being emptied.

When snorkeling pools upstream from the dam, we counted 16 bull trout $\geq 300 \mathrm{~mm}$ FL, 10 of which were unmarked. We captured no fluvial adult-sized bull trout when electrofishing riffles and glides or riffle/pool units. The abundance estimate for unmarked fish $\geq 300 \mathrm{~mm}$ FL, therefore, was based solely on snorkel counts in pools and was equal to 32 (Table 4).

We estimated that 106 mature fluvial females were present in the drainage upstream from the dam. Eighty-eight were captured and identified at the trap. Approximately half (49\%) of the fish inspected for maturity were mature females. Therefore, we assumed that two of the three fish trapped before our ultrasound equipment arrived and 16 of the estimated 32 unmarked fish $\geq$ $300 \mathrm{~mm}$ FL upstream from the dam were mature females.

Table 3. Number, sex, and maturity status of bull trout captured in an upstream migrant trap in Mill Creek in 2002. Sex and maturity status were determined using ultrasound. Mature males, and the sex of immature fish, could not be identified via ultrasound. Trapping data for mountain whitefish Prosopium williamsoni, which were the only other species captured, are also included.

\begin{tabular}{|c|c|c|c|c|}
\hline & $\begin{array}{l}\text { Mature } \\
\text { females }\end{array}$ & $\begin{array}{l}\text { Mature males and } \\
\text { immature males } \\
\text { and females }\end{array}$ & Unknown & \\
\hline bull trout & 88 & $89^{\mathrm{a}}$ & $4^{b}$ & 181 \\
\hline Mountain whitefish & & & 5 & 5 \\
\hline
\end{tabular}


Table 4. Number of pools in the mainstem of Mill Creek, number of pools sampled, and mean density (number per pool) and estimated abundance of unmarked bull trout $\geq 300 \mathrm{~mm}$ FL in 2002.

\begin{tabular}{ccccc}
\hline Stratum & $\begin{array}{c}\text { No. of } \\
\text { pools }\end{array}$ & $\begin{array}{c}\text { No. of pools } \\
\text { sampled }\end{array}$ & $\begin{array}{c}\text { Mean fish } \\
\text { density }\end{array}$ & $\begin{array}{c}\text { Estimated } \\
\text { no. of fish }\end{array}$ \\
\hline $1^{\mathrm{a}}$ & 38 & 12 & 0.17 & 6 \\
$2^{\mathrm{b}}$ & 111 & 35 & 0.23 & $\underline{26}$ \\
& & & & 32 \\
\hline
\end{tabular}

${ }^{a}$ from the diversion dam to a point approximately $1000 \mathrm{~m}$ upstream from the mouth of Paradise Creek.

${ }^{b}$ from the upper limit of stratum 1 to the headwaters of Mill Creek.

We identified no mature females among 54 fish $<300 \mathrm{~mm}$ FL that were inspected internally via endoscopy (Tables 5 and 6). Therefore, we estimated that no mature resident females were present in the Mill Creek drainage upstream from the dam. Combining estimates for mature fluvial (106) and resident (0) females yielded an estimated total of 106 mature females.

We counted 213 redds in Mill Creek and its tributaries (Table 7). Most of the redds were in the mainstem of Mill Creek. Low Creek contained more redds than any other tributary. The discrepancy between the redd count (213) and the estimated number of mature females (106) in the study area might indicate the redd count was inaccurate and positively biased. It is possible, however, that some females made more than one redd, or that we underestimated the number of unmarked, fluvial adult-sized fish in the system and, hence, the number of unmarked, mature fluvial females. We did not calibrate our counts of fluvial adult-sized fish in pools according to our snorkeling efficiency, and those counts may have been negatively biased. It is also possible that some females jumped the dam after we completed the snorkel counts. Finally, although we found no mature resident females during endoscopic examinations and estimated that none were present in the drainage, we did observe some resident-sized females spawning in Low Creek. Based on the low number of relatively small redds we observed, we suspect the difference between the redd count and estimated number of mature females was not entirely due to our failure to account for the mature resident females. 
Table 5. Location, number, sex, and maturity status of bull trout $<300 \mathrm{~mm}$ FL sampled in Mill Creek and its tributaries in 2002. Sex and maturity status were determined via endoscopic examination of reproductive organs. The sex of immature fish could not be determined.

\begin{tabular}{|c|c|c|c|c|}
\hline \multirow[b]{2}{*}{ Stratum } & \multicolumn{2}{|c|}{ Mature } & \multirow[b]{2}{*}{ Immature } & \multirow[b]{2}{*}{ Total } \\
\hline & Female & Male & & \\
\hline Mill Cr 1 & 0 & 4 & 15 & 20 \\
\hline Mill Cr 2 & 0 & 8 & 17 & 25 \\
\hline Low $\mathrm{Cr}$ & 0 & 0 & 0 & 0 \\
\hline Paradise $\mathrm{Cr}$ & 0 & 0 & 3 & 3 \\
\hline NF Mill Cr & 0 & 0 & 0 & 0 \\
\hline Burnt Fork $\mathrm{Cr}$ & 0 & 0 & 0 & 0 \\
\hline Bull Cr & 0 & 1 & 6 & 7 \\
\hline Total & 0 & 13 & 41 & 54 \\
\hline
\end{tabular}

Table 6. Length and maturity status of bull trout $<300 \mathrm{~mm}$ FL sampled in Mill Creek and its tributaries in 2002. Sex and maturity status were determined determined via endoscopic examination of reproductive organs. The sex of immature fish could not be determined.

\begin{tabular}{cccc}
\hline & & \multicolumn{2}{c}{ Mature } \\
\cline { 3 - 3 } Fork Length & Immature & Female & Male \\
$110-119$ & 1 & & \\
$120-129$ & 2 & & \\
$130-139$ & 1 & & 1 \\
$140-149$ & 10 & & 1 \\
$150-159$ & 8 & & 2 \\
$160-169$ & 14 & & 1 \\
$170-179$ & 1 & & 1 \\
$180-189$ & 3 & & 1 \\
$190-199$ & 1 & & 1 \\
$200-209$ & & & 2 \\
$210-219$ & & & 13 \\
$220-229$ & & & \\
$230-239$ & & & \\
$240-249$ & & & \\
$250-259$ & 41 & & \\
Total & & & \\
\hline
\end{tabular}


Table 7. Redd counts in Mill Creek in 2002. The locations of survey sections are shown in Figure 3.

\begin{tabular}{cc}
\hline Survey section & No. of redds \\
\hline 1 & 0 \\
2 & 0 \\
3 & 2 \\
4 & 40 \\
5 & 80 \\
6 & 24 \\
7 & 15 \\
Low Cr & 32 \\
Paradise Cr & 5 \\
N.F. Mill Cr & 12 \\
Deadman Cr & 0 \\
Burnt Fork Cr & 2 \\
Bull Cr & 1 \\
& \\
All & 213 \\
\hline
\end{tabular}




\section{Monitoring the abundance of adult bull trout in the Walla Walla, Umatilla, John Day, and Deschutes River subbasins using the Environmental Monitoring and Assessment Program (EMAP) protocol}

\section{Introduction}

The ability to accurately assess bull trout population status, trend, and distribution is central to conservation efforts for the species. A coordinated approach to conducting such assessments is needed to support restoration efforts. Currently, most monitoring activities are not part of an overall framework for coordinating effort and synthesizing and interpreting results. The Environmental Protection Agency (EPA) has developed the Environmental Monitoring and Assessment Program (EMAP) to evaluate the status of natural resources at regional and national scales. The goal of EMAP is to provide a scientific basis for monitoring programs that measure current and changing resource status.

EMAP employs a probabilistic sampling design that allows resource assessment over large areas based on data from representative sample locations. The design involves a spatially balanced random sampling strategy that distributes sample locations evenly throughout the area of assessment. Trends in status are best assessed by visiting randomly selected sampling sites on annual and multi-year cycles. The EMAP sampling design allows evaluation of status, trend, and distribution at multiple scales with statistical rigor.

In 2002, we implemented the EMAP protocol to monitor the abundance of adult bull trout in the Deschutes, John Day, Umatilla, and Walla Walla River subbasins. We used redd counts to assess adult abundance. Counting redds is the easiest and often the least costly way to estimate adult abundance. Although there can be substantial error associated with the enumeration of redds (Bonneau and LaBar 1997; Dunham et al. 2001; Hemmingsen et al. 2001b), research has shown that redd counts are strongly correlated with estimates of adult escapement (Dunham et al. 2001).

\section{Methods}

The sampling frames in the four subbasins consisted of all wadable stream reaches that contain current and potential bull trout spawning habitat. The identification of these reaches was based on ODFW maps of current distribution (derived from the EPA's 1:100k river reach data set) and input from ODFW district biologists and other fishery managers via Streamnet's (http:// www.streamnet.org) 1:24K mapping effort. We included only wadable stream reaches because redds can be difficult to count effectively in unwadable areas. The sampling frame was the pool of possible locations from which sample sites were selected and represents our scope of inference.

Site selection was conducted by the EPA Research Lab in Corvallis, Oregon. The site selection process is based on a spatial grid design with hexagonal areas centered at grid points (Stevens and Olsen 1999). Points along all streams in the sampling frame were plotted 
sequentially by computer and then randomly selected. The randomly selected points were then re-plotted on maps for survey site location.

The number of sample sites within subbasins was based on the minimum number of sites necessary to quantify status and detect trends over time. Our target measure of precision for the estimated number of redds was $\pm 45 \%$ at the subbasin scale and $\pm 25 \%$ at the provincial (all subbasin combined) scale. The spawning distributions in the Walla Walla and Umatilla subbasins were limited, so they were combined and the two subbasins were treated as an aggregate when selecting sites. The site selection process produced 50 spatially balanced sites in each of the Deschutes, John Day, and combined Walla Walla-Umatilla subbasins. We thought 50 sites would be the maximum number a crew of two surveyors could effectively survey multiple times throughout the spawning period. We determined that a minimum of 30 sites should be surveyed per subbasin. Fifty additional sites were selected in each subbasin for use as replacements in the event some sites were unsuitable (e.g., located in a dry stream channel) or on private property we could not get permission to access.

During August, field crews located each sample point using Universal Transverse Mercator (UTM) coordinates, maps, and a GPS receiver. The suitability of each site was judged by the presence of adequate spawning habitat and the absence of barriers to bull trout migration, unless bull trout were known to exist upstream from a barrier. Each sample point served as the mid-point of a $1.6 \mathrm{~km}$ spawning survey section. End-points were determined by measuring 0.8 $\mathrm{km}$ upstream and downstream from the mid-point. Survey end-points were flagged with surveyor's tape, and plastic identification signs were fixed to a nearby tree on the stream bank. UTM coordinates of survey section end-points were recorded with GPS receivers and marked on a map.

From early September through early November, all sites in each subbasin were surveyed three or four times. Four survey crews of two individuals each conducted the surveys. The four crews were separately responsible for surveys in the Deschutes subbasin, Middle Fork and upper John Day River drainages, North Fork John Day River drainage, and Walla Walla-Umatilla subbasin. Crews were trained in the identification of bull trout redds, and spawning surveys were conducted according to ODFW protocols (Bellerud 1997). During the surveys, each newly observed redd was recorded and flagged. In streams where the presence of sympatric fallspawning species made bull trout redd identification difficult, redds were attributed to bull trout only if bull trout were observed on them.

Bull trout population status was assessed based on cumulative redd counts. These counts were analyzed using analytical algorithms developed by the EMAP (Stevens 2002). To assess the accuracy of the EMAP estimates, we also surveyed the entire sampling frame (full census) in the Walla Walla-Umatilla subbasin. The census surveys were conducted multiple times throughout the spawning period, as for the EMAP surveys. The total redd count within the sampling frame was compared to the estimated number of redds obtained using the EMAP protocol. 


\section{Results and Discussion}

Using the EMAP sampling strategy, we estimated there were 1,704 $( \pm 487), 541( \pm 209)$, and 716 $( \pm 164)$ redds in the Deschutes, John Day, and Walla Walla-Umatilla subbasins, respectively, and 2,930 $( \pm 555)$ redds in the province in 2002 (Table 8). The precision of the estimates was well within our target of $\pm 45 \%$ for the individual subbasins and $\pm 25 \%$ for the province (Table 9). The accuracy of the EMAP estimate for the Walla Walla-Umatilla subbasin appeared to be quite good, differing from the redd count obtained from the census surveys by only 2\% (Table 9). Although additional effort was required to locate and set up sites for the EMAP surveys, the total effort expended was considerably less than that needed to complete the census surveys. The EMAP surveys covered 51\% of the stream kilometers encompassed in the census surveys (Table 9).

Table 8. Bull trout redds counted in survey sections (n) and estimated to be within three subbasins in 2002.

\begin{tabular}{cccc}
\hline Subbasin & $\mathrm{n}$ & $\begin{array}{c}\text { Estimated } \\
\text { no. of redds }\end{array}$ & C.I. $(\%)^{\text {a }}$ \\
\hline Deschutes & 34 & 1,704 & 29 \\
John Day & 42 & 541 & 39 \\
Walla Walla- & 40 & 716 & 23 \\
Umatilla & & & \\
Province & 116 & 2,930 & 19 \\
${ }^{\mathrm{a}} \pm$ 95\% confidence interval. &
\end{tabular}

Table 9. Comparison of two strategies used to count bull trout redds in the Walla Walla-Umatilla subbasin in 2002.

\begin{tabular}{ccc}
\hline & Census & EMAP \\
\hline Number of redds & 730 & 716 \\
Stream km surveyed & 115 & 59 \\
\hline
\end{tabular}

The precision of our EMAP estimates could be improved in the future by increasing the number of survey sections within subbasins and refining the sampling frames and survey protocol. In 2002, we sampled more than the minimum number (30) of sites in each subbasin (Table 8), but were unable to sample the desired 50 sites, primarily due to denial of access (Figures 4-6). The Deschutes River subbasin was a particular problem in this regard, with access being denied to sites on Shitike Creek and the Warm Springs and Whitewater rivers. Because of initial errors in the GIS coverage used for sample site selection, eight sites in the Walla WallaUmatilla subbasin were located outside the sampling frame and not surveyed (Figure 4). 
The EMAP estimate for the John Day River subbasin was the most imprecise of the estimates for the three subbasins. This was due partly to our having surveyed only $25 \%$ of the relatively large sampling frame in John Day River subbasin, compared to $40 \%$ and $51 \%$ of the sampling frames in the Deschutes and Walla Walla-Umatilla River subbasins, respectively. It was also due to the relatively low site occupancy rate (proportion of survey sections in which redds were identified) in the John Day River subbasin. In that subbasin, as well as in the Deschutes River subbasin, redds were recorded in only $53 \%$ of the survey sections. Under the EMAP protocol, it is expected that some sites will be unoccupied and that changes in fish distribution through time will be reflected by changes in site occupancy rates and the distribution of occupied sites. The site occupancy rates we observed may have been artificially low, however. In some drainages, current and potential spawning distributions were based largely on professional judgement rather than existing data, and we may have surveyed some stream reaches that should have been excluded from the sampling frames. In addition, in areas where fall-spawning species other than bull trout were present, we recorded only redds occupied by bull trout. We may have recorded no bull trout redds in survey sections that actually contained them as a result.

Given the potential problems with the sampling frames and identification of bull trout redds in the John Day and Deschutes River subbasins, it is possible the EMAP estimates for those subbasins were not as accurate as the estimate for the Walla Walla-Umatilla subbasin appeared to be. Including reaches in the sampling frames that should have been excluded would have led to an overestimate of the number of redds, whereas failing to identify bull trout redds would have led to an underestimate.

In the future, we will modify the spawning survey protocol in reaches with sympatric fall-spawning species so that bull trout redds can be better identified. One approach we are considering is to conduct surveys more frequently to increase the probability of observing bull trout on redds. We will also survey 50 new, randomly selected sites per subbasin in each of the next two years. This sampling design will allow us to further refine the known bull trout spawning distributions and sampling frames. With improvements to the survey protocol and refinements in the sampling frames, we expect the accuracy and precision of our estimates to improve. After this three-year pilot study, we intend to use a sampling design in which a proportion of sites will be visited annually or on a multi-year cycle to better evaluate bull trout population status, trend, and distribution in the three subbasins. 
Figure 4. Location, status and number of bull trout redds $/ \mathrm{km}$ for sample sites in a) Walla Walla River and b) Umatilla River subbasins, OR.

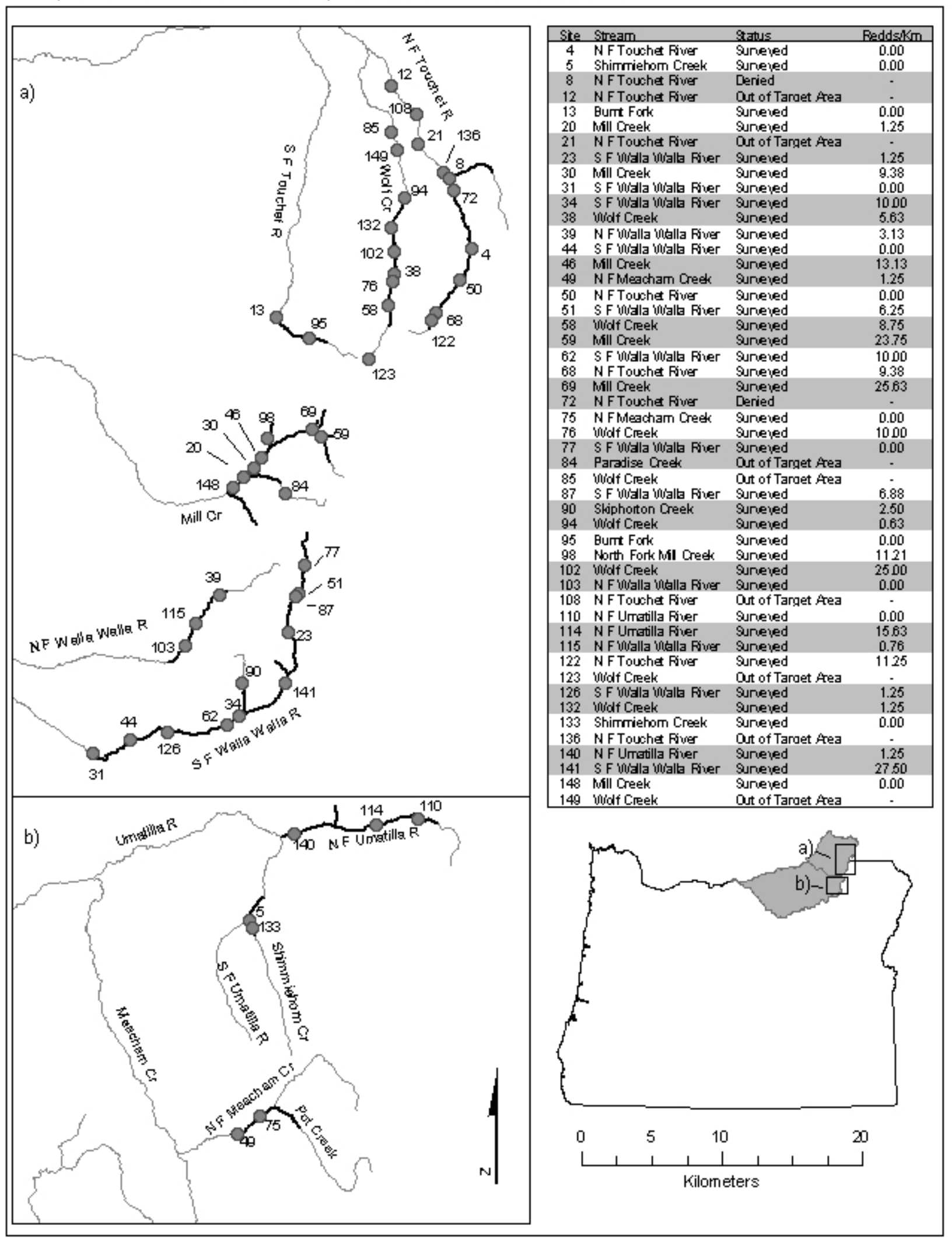


Figure 5. Location, status, and number of bull trout redds $/ \mathrm{km}$ for sample sites in a) North and Middle Forks and b) Mainstem John Day River subbasins, OR.

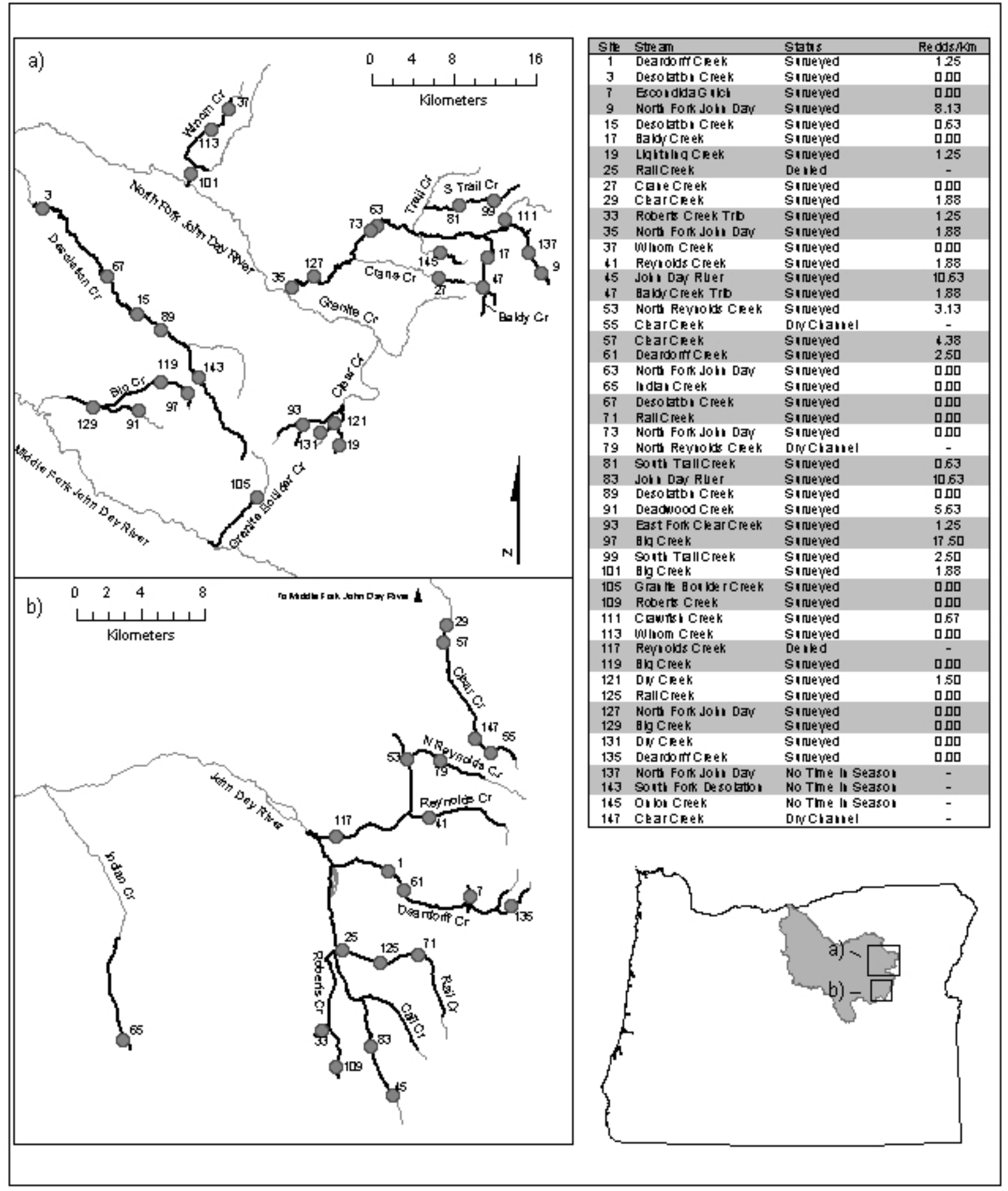


Figure 6. Sample sites, status and number of bull trout redds $/ \mathrm{km}$ for sample sites located in a) Warm Springs and b) Metolius basins, OR.

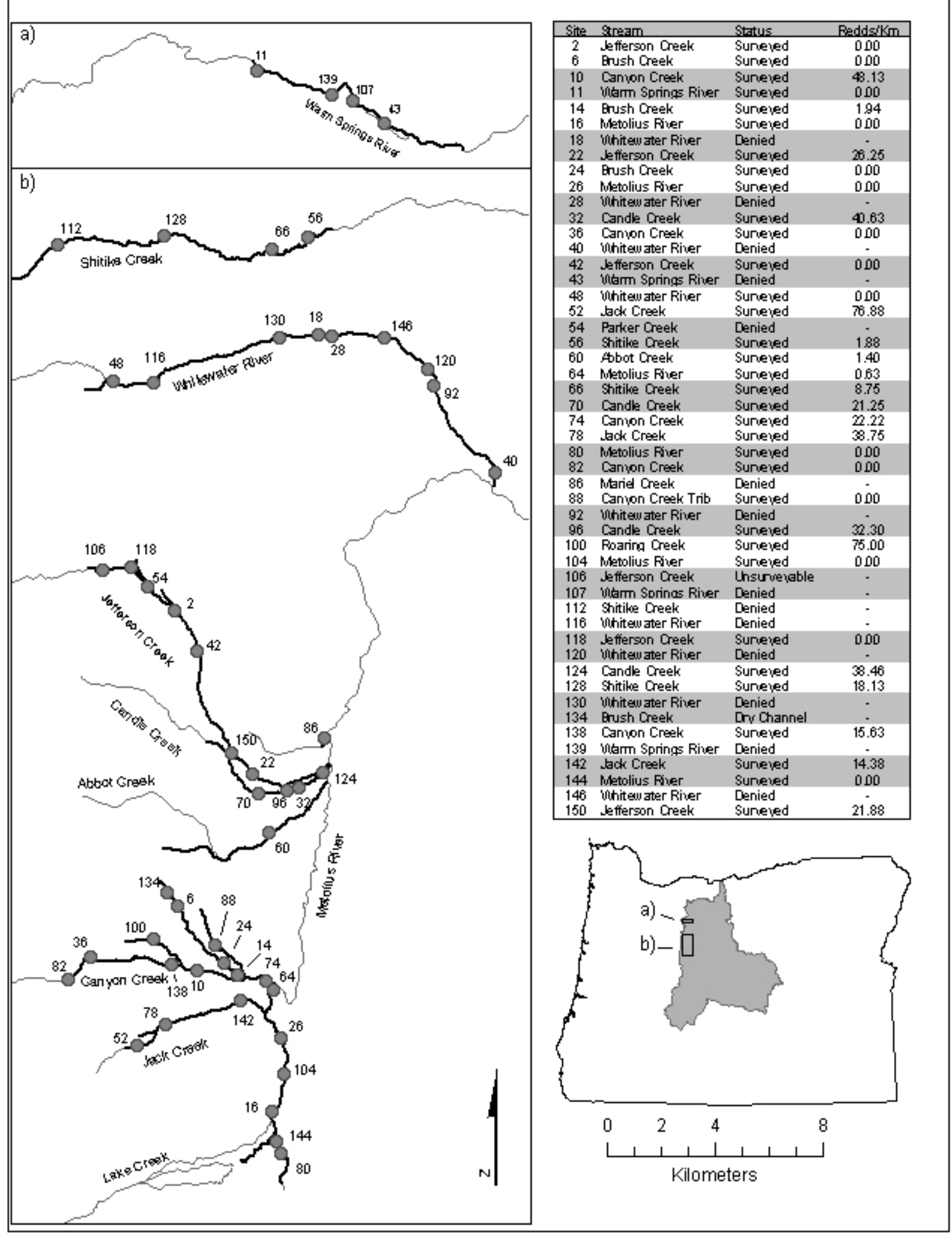




\section{Acknowledgements}

We are grateful to the following individuals for their assistance in conducting field work: Rodger Johnson, Spencer Johnson, Larry Boe, Steve Starcevich, Alex Higgins, Alex Lauber, Jaime Kissner, Erica McCormick, Renee Ripley, Jenny Severson, Matt Bernart, Nat Davis, Kevin Saylor, Ben Goodman, and Tanya Johnston. We thank Senior Trooper Ken West of the Oregon State Police for piloting the aircraft we used for telemetry flights. 


\section{References}

Bellerud, B.L., S. Gunckel, A.R. Hemmingsen, D.V. Buchanan, and P.J. Howell. 1997. Bull trout life history, genetics, habitat needs and limiting factors in central and northeast Oregon, 1996 annual report. Project 199405400, Bonneville Power Administration, Portland, OR.

Bonar, S.A., M. Divens, and B. Bolding. 1997. Methods for sampling the distribution and abundance of bull trout and Dolly Varden. Washington Department of Fish and Wildlife, Olympia, WA.

Bonneau, J., and LaBar. 1997. Interobserver and temporal bull trout redd count variability in tributaries to of Lake Pend Oreille, Idaho: Completion Report. Department of Fisheries and Wildlife, University of Idaho, Moscow.

Buchanan, D.V., M. Hanson, and B. Hooton. 1997. Bull trout status report for Oregon. Oregon Department of Fish and Wildlife. Portland, OR.

Dunham, J., B. Rieman, and K. Davis. 2001. Sources and magnitude of sampling error in redd counts for bull trout Salvelinus confluentus. North American Journal of Fisheries Management 21: 343-352.

Fraley, J. J., and B. B. Shepard. 1989. Life history, ecology, and population status of migratory bull trout (Salvelinus confluentus) in the Flathead Lake river system, Montana. Northwest Science 63 (4): 133-143.

Hankin, D.G., and G.H. Reeves. 1988. Estimating total fish abundance and total habitat area in small streams based on visual estimation methods. Canadian Journal of Fisheries and Aquatic Sciences 45: 834-844.

Hemmingsen, A.R., S.L. Gunckel, P.M. Sankovich, and P.J. Howell. 2001a. Bull trout life history, genetics, habitat needs, and limiting factors in central and northeast Oregon. 2000 Annual Report. Project 199405400, Bonneville Power Administration. Portland, OR.

Hemmingsen, A.R., B.L. Bellerud, and S.L. Gunckel. 2001b. Bull trout life history, genetics, habitat needs, and limiting factors in central and northeast Oregon. 1998 Annual Report. Project 199405400, Bonneville Power Administration. Portland, OR.

Hemmingsen, A.R., S.L. Gunckel, and P.J. Howell. 2001c. Bull trout life history, genetics, habitat needs, and limiting factors in central and northeast Oregon. 1999 Annual Report. Project 199405400, Bonneville Power Administration. Portland, OR. 
Hemmingsen, A.R., S.L. Gunckel, J.S. Shappart, B.L. Bellerud, D.V. Buchanan, and P.J. Howell. 2001d. Bull trout life history, genetics, habitat needs, and limiting factors in central and northeast Oregon. 1997 Annual Report. Project 199405400, Bonneville Power Administration. Portland, OR.

Hemmingsen, A.R., S.L. Gunckel, P.M. Sankovich, and P.J. Howell. 2002. Bull trout life history, genetics, habitat needs, and limiting factors in central and northeast Oregon. 2001 Annual Report. Project 199405400, Bonneville Power Administration. Portland, OR.

Maxell, B. A. 1999. A prospective power analysis on the monitoring of bull trout stocks using redd counts. North American Journal of Fisheries Management 19:860-866.

Pratt, K.L. 1992. A review of bull trout life history. Pages 5-9 in P.J. Howell and D.V. Buchanan, editors. Proceedings of the Gearhart Mountain Bull Trout Workshop. Oregon Chapter of the American Fisheries Society, Corvallis.

Rieman, B.E., and J.B. Dunham. 2000. Metapopulations and salmonids: a synthesis of life history patterns and empirical observations. Ecology of Freshwater Fish 9:51-64.

Rieman, B.E., and J.D. McIntyre. 1993. Demographic and habitat requirements for conservation of bull trout. General Technical Report INT-302, Intermountain Research Station, Ogden, UT.

Rieman, B.E., and D.L. Myers. 1997. Use of redd counts to detect trends in bull trout (Salvelinus confluentus) populations. Conservation Biology 11(4): 1015-1018.

Spruell, P., and F.W. Allendorff. 1997. Nuclear DNA analysis of Oregon bull trout, Report 97/5. Oregon Department of Fish and Wildlife. Portland, OR.

Spruell, P, A.R. Hemmingsen, P.J. Howell, N. Kanda, and F.W. Allendorf. 2003. Conservation genetics of bull trout: geographic distribution of variation at microsatellite loci. Conservation Genetics 4: 17-29.

Spruell P., B.E. Rieman, K.L. Knudsen, F. M. Utter, and F.M. Allendorf. 1999. Genetic population structure within streams: microsatellite analysis of bull trout populations. Ecology of Freshwater Fish 8: 114-121.

Stevens, D.L., Jr. 2002. Sampling design and statistical analysis methods for integrated biological and physical monitoring of Oregon streams. OPSW-ODFW-2002-07, Oregon Department of Fish and Wildlife, Portland, Oregon.

Stevens, D.L., Jr., and A.R. Olsen. 1999. Spatially restricted surveys over time for aquatic resources. Journal of Agriculture, Biological, and Environmental Statistics 4: 415-428. 
U.S. Fish and Wildlife Service. 2002. Chapter 11, Umatilla-Walla Walla Recovery Unit, Oregon and Washinton. 153 p. In: U.S. Fish and Wildlife Service. Bull Trout (Salvelinus confluentus) Draft Recovery Plan. Portland, Oregon. 
Appendix A. Movements of radio-tagged bull trout in the Umatilla River subbasin 
150.162
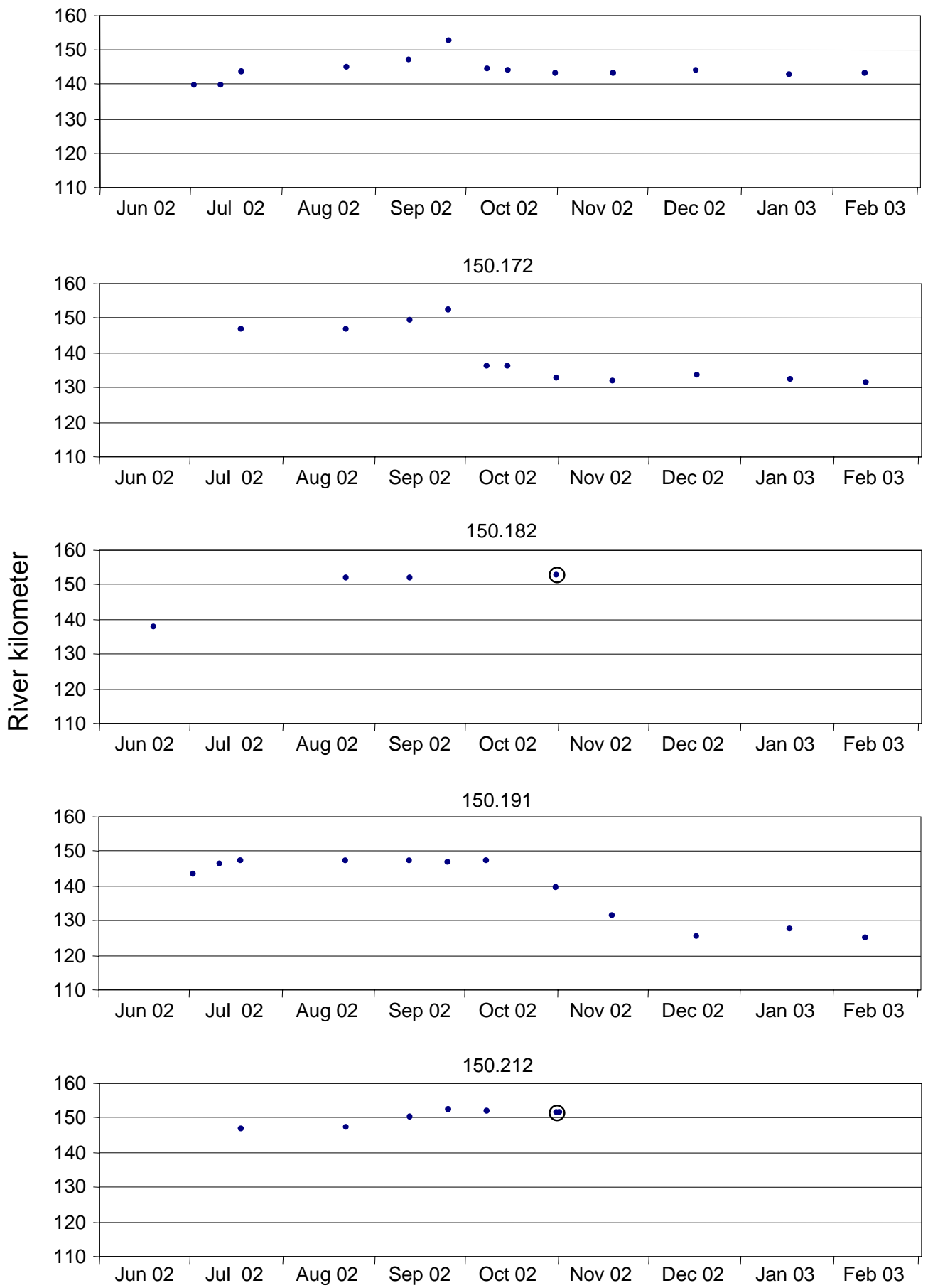

Appendix Figure A-1. Locations of bull trout with radio tag freqencies 150.162, 150.172, 150.182, 150.191, and 150.212 during tracking events from June 2002 through February 2003. River kilometers (RKm) are continuous from the mouth of the Umatilla River into the North Fork Umatilla River. The North Fork Umatilla River enters the Umatilla River at RKm 144. Circled locations indicate tag recoveries (i.e., the fish was dead or had rejected its tag). 

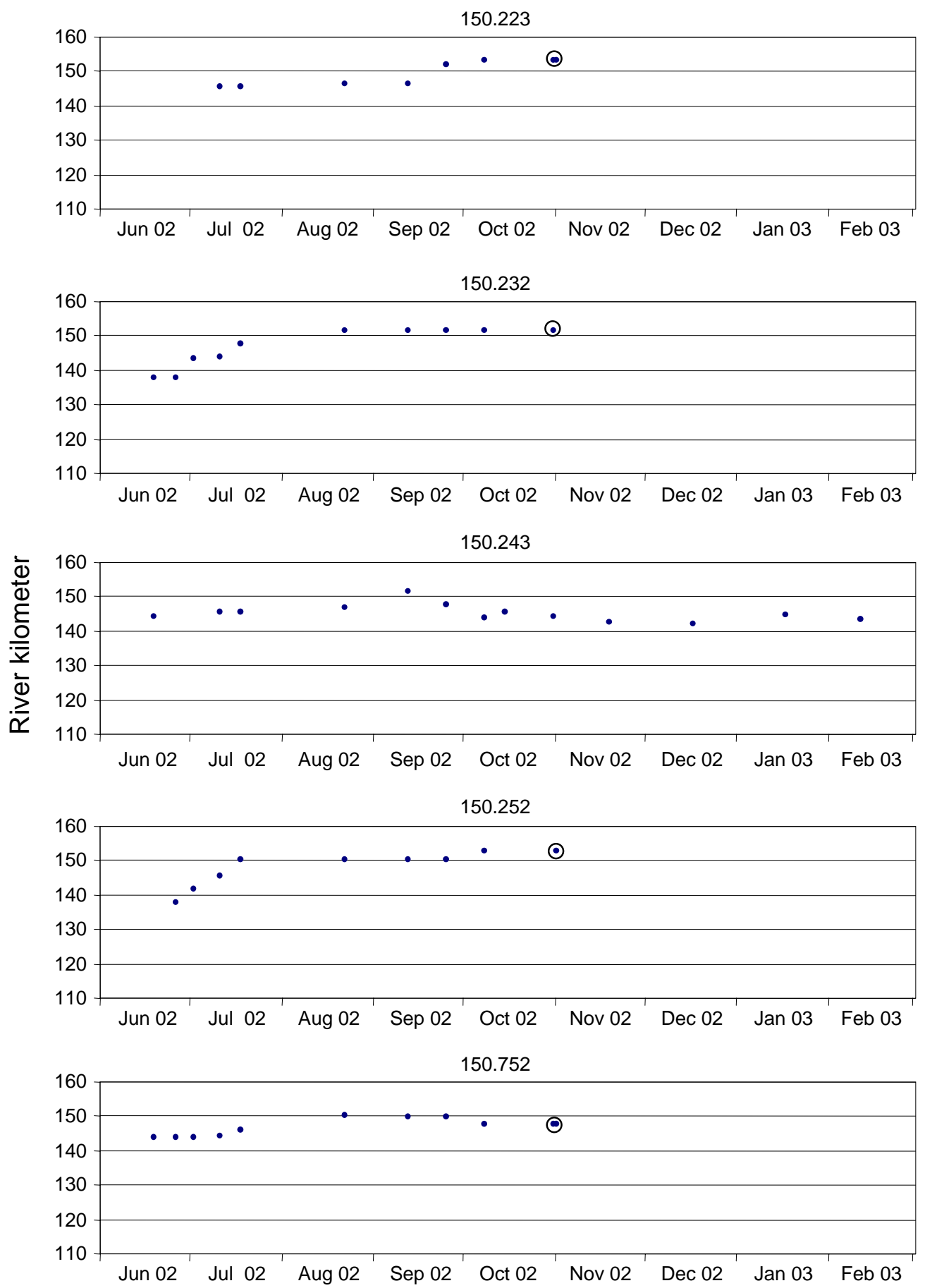

Appendix Figure A-2. Locations of bull trout with radio tag freqencies 150.223, 150.232, 150.243, 150.252, and 150.752 during tracking events from June 2002 through February 2003. River kilometers (RKm) are continuous from the mouth of the Umatilla River into the North Fork Umatilla River. The North Fork Umatilla River enters the Umatilla River at RKm 144. Circled locations indicate tag recoveries (i.e., the fish was dead or had rejected its tag). 

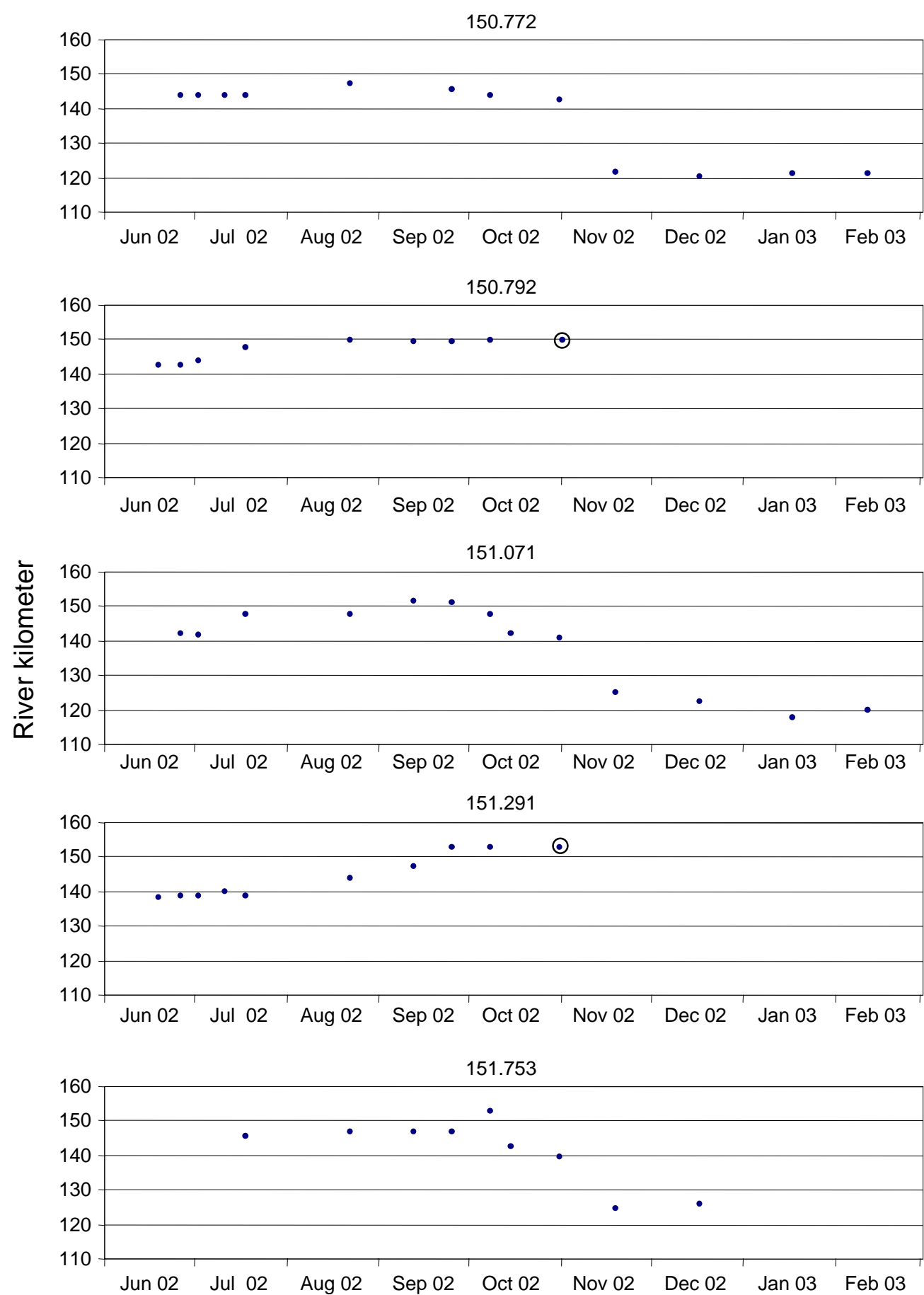

Appendix Figure A-3. Locations of bull trout with radio tag freqencies 150.772, 150.792, 151.071, 151.291, and 151.753 during tracking events from June 2002 through February 2003. River kilometers (RKm) are continuous from the mouth of the Umatilla River into the North Fork Umatilla River. The North Fork Umatilla River enters the Umatilla River at RKm 144. Circled locations indicate tag recoveries (i.e., the fish was dead or had rejected its tag). 
Appendix Table A-1. Locations of radio-tagged bull trout in the Umatilla and North Fork Umatilla rivers during tracking events from June 2002 to February 2003. River kilometers (RKm) are continuous from the mouth of the Umatilla River into the North Fork Umatilla River. The North Fork Umatilla River enters the Umatilla River at RKm 144. River kilometers in italics indicate tag recoveries (i.e., the fish was dead or had rejected its tag).

\begin{tabular}{|c|c|c|c|c|c|c|c|c|c|c|c|c|c|c|c|}
\hline \multirow[b]{2}{*}{ Date } & \multicolumn{15}{|c|}{ Radio tag frequency } \\
\hline & 150.162 & 150.172 & 150.182 & 150.191 & 150.212 & 150.223 & 150.232 & 150.243 & 150.252 & 150.752 & 150.772 & 150.792 & 151.071 & 151.291 & 151.753 \\
\hline $6 / 19 / 02$ & & & 137.6 & & & & 137.6 & 144.4 & & 143.6 & & 142.3 & & 138.3 & \\
\hline $6 / 26 / 02$ & & & & & & & 137.6 & & 137.6 & 143.6 & 143.6 & 142.3 & 142.0 & 138.7 & \\
\hline $7 / 2 / 02$ & 139.9 & & & 143.2 & & & 143.2 & & 141.8 & 143.6 & 143.6 & 143.6 & 141.8 & 138.4 & \\
\hline $7 / 11 / 02$ & 139.9 & & & 146.3 & & 145.5 & 143.6 & 145.5 & 145.5 & 144.0 & 143.6 & & & 139.9 & \\
\hline $7 / 18 / 02$ & 143.6 & 146.6 & & 147.2 & 146.8 & 145.3 & 147.4 & 145.6 & 150.0 & 145.8 & 143.6 & 147.6 & 147.7 & 138.4 & 145.5 \\
\hline $8 / 22 / 02$ & 145.0 & 146.8 & 151.9 & 147.1 & 147.2 & 146.4 & 151.6 & 146.8 & 150.1 & 150.0 & 147.1 & 149.7 & 147.6 & 143.6 & 146.9 \\
\hline $9 / 25 / 02$ & 152.7 & 152.4 & & 146.9 & 152.2 & 151.7 & 151.3 & 147.4 & 150.0 & 149.8 & 145.5 & 149.5 & 151.1 & 152.5 & 146.9 \\
\hline $10 / 8 / 02$ & 144.5 & 135.9 & & 147.1 & 152.1 & 153.0 & 151.4 & 143.9 & 152.7 & 147.4 & 143.6 & 149.7 & 147.4 & 152.7 & 152.5 \\
\hline $10 / 15 / 02$ & 144.2 & 135.9 & & & & & & 145.6 & & & & & 142.1 & & 142.3 \\
\hline $10 / 31 / 02$ & 143.1 & 132.8 & 152.9 & 139.4 & 151.3 & 153.0 & 151.4 & 144.0 & & 147.7 & 142.6 & & 140.7 & 152.7 & 139.4 \\
\hline $11 / 1 / 02$ & & & & & 151.4 & 153.0 & & & 152.7 & 147.4 & & 149.7 & & & \\
\hline $11 / 19 / 02$ & 143.1 & 131.8 & & 131.2 & & & & 142.4 & & & 121.7 & & 125.0 & & 124.6 \\
\hline $12 / 17 / 02$ & 144.0 & 133.3 & & 125.6 & & & & 142.1 & & & 120.5 & & 122.5 & & 125.9 \\
\hline $2 / 11 / 03$ & 143.4 & 131.2 & & 125.0 & & & & 143.2 & & & 120.9 & & 120.0 & & \\
\hline
\end{tabular}

